\title{
A STUDY ON THE COMBINING ABILITY IN CHILLI PEPPER (Capsicum annuum L. AND Capsicum chinense Jacq.) USING LINE $\times$ TESTER ANALYSIS
}

( Received: 13.1.2008) \author{
By
A.H. Khereba, A. A.Gharib, S. M. Mahmoud , Y. M. Ahmed, and A.A. El-Sayed \\ Vegetable Crops Department, Faculty of Agriculture, Cairo University, Giza, Egypt. \\ Vegetable Research Department, Horticulture Research Institute, Agricultural Research \\ Center, Giza, Egypt.
}

\begin{abstract}
Seven chilli pepper PIs obtained from USDA were used in this study. Four PIs belong to Capsicum annuum, viz., 159233, 138563, 142837and 166988 (used as line) and three PIs belong to Capsicum chinense, viz., 209028, 159241 and 159236 (used as tester) were crossed in a line $\times$ tester mating design to calculate the effects of the combining ability for eight characters, plant height, earliness, average fruit weight, fruit diameter, fruit length, fruit flesh thickness, early yield and total yield during 2005-2006 under unheated plastic house at Kaha Experimental Station, Kaliobia Governorate.

Significant differences were found among the tested genotypes for all studied traits except for fruit flesh thickness. The non additive gene effect played the major role in the inheritance of all characters except for the number of days to flowering. General combining ability (GCA) estimates for the parent P1166988 showed that it was the best parent for early yield. Specific combining ability (SCA) estimated for the cross PI $166988 \times$ PI 159236 showed that it was the best cross for plant height, number of days to flowering, average fruit weight, fruit length, fruit diameter and total yield.
\end{abstract}

Key words : chilli pepper, combining ability, line $\times$ tester analysis.

\section{INTRODUCTION}

Pepper, Capsicum annuum L. is one of the most important and widely consumed among the grown vegetable crops in Egypt. The maximum total productivity by developing new cultivar or $\mathrm{F}_{1}$ hybrid through breeding programs are generally utilized under protected cultivation. Success in programs of crop improvement mainly depends on the good selection of parents together with the information concerned to the nature and magnitude of gene effects controlling quantitative traits of economic importance. Determining of gene effects and combining ability not only provide information on inheritance of the characters but also help in selection of suitable parents for hybridization and development of promising hybrids.

Genotypic variance includes additive, dominance and epistatic effects of genes. Information about the relative importance of additive and non additive gene action could help in selecting suitable breeding schemes.

Velaskes (1981) mentioned that the additive component played the major role for the number of days to flowering. Miranda et al. (1988 a \&b) stated that non additive component played the major role for plant height. Khalil et al. (1989) found that the additive gene effects showed significant value and were more important than dominance effects in total yield, meanwhile, the non additive component played the major role for fruit diameter. Ahmed et al. (1997) mentioned that the additive component played the major role for the number of days to flowering. Mulge and Anand (1997) reported that additive component played the major role for average fruit weight. Patel et al. (1998) mentioned that plant height, the number of fruits per plant, fruit length, fruit weight and green fruit yield per plant are predominantly controlled by additive gene effect. Khereba et al. (2004) reported that fruit diameter, early yield and total yield were controlled by non additive gene, meanwhile, additive component played the major role for fruit flesh thickness.

On the other hand, Ahmed et al. (1998) mentioned that the variances due to general combining ability (GCA) and specific combining ability (SCA) were significant for all the characters except for days to first fruit ripening. This indicates that both additive and non-additive gene effects were involved in the genetic control. 
The objective of the current study was to produce a new local pepper $F_{1}$ hybrid and compare the general and specific combining ability effects in pepper crosses.

\section{MATERIALS AND METHODS}

This experiment was conducted at Kaha Experimental Station, Kaliobia Governorate under unheated plastichouse $(9 \mathrm{~m} \times 59 \mathrm{~m}, 4 \mathrm{~m}$ height $)$ during the period from 2004 to 2007. Seven pepper PIs obtained from the USDA were used in this study. Four PIs belong to Capsicum annuum, viz., 159233, 138563, 142837and 166988 (used as line) and three PIs belong to Capsicum chinense, viz., 209028, 159241 and 159236 (used as tester) were planted during the season of 2004/2005 for selfing to insure the purity of these PIs. The obtained selfed seeds from this season were planted inside the greenhouse during the second season (2005-2006) and were crossed to produce the $F_{1}$ seeds in a line $\times$ tester mating design.

Seeds of the seven parental lines and their twelve $F_{1}$ crosses were sown in seedling trays on the $1^{\text {st }}$ of July, 2006. Forty five days after seeding, pepper seedlings were transplanted inside a plastichouse in a randomized complete block design with three replicates. Plot area was $5 \mathrm{~m}$ wide and $2.5 \mathrm{~m}$ long obtained 10 plants and spaces between plants were $50 \mathrm{~cm}$.

Standard cultural practices were adopted as recommended by the Ministry of Agriculture. Data were recorded for the following characters:

1. Plant height was measured as the mean height of 10 plants from each replicate at the end of the season.

2. Earliness of flowering was measured as the number of days required for the anthesis of first flower from all plants in each replicate.

3. Average fruit weight was measured as the mean of five fruits randomly selected from all plants in each replicate.

4. Fruit diameter was measured at the shoulder of the fruit by caliper for five fruits randomly selected from all plants in each replicate.

5. Fruit length was measured from the top to end of the fruit by caliper for five fruits randomly selected from all plants in each replicate.

6. Fruit flesh thickness was measured at the middle of the fruit for five fruits randomly selected from all plants in each replicate.

7. Early yield was measured as average weight of fruits per plant for first four harvests from all plants in each replicate. Harvesting continued for two weeks.

8. Total yield was measured as average weight of fruits per plant for all harvests (10 plants from each replicate).

Means and variances were obtained for each population and the means were statistically compared for significant differences using new L.S.D. (Waller and Duncan, 1969).

General and specific combining abilities were estimated using line $\times$ tester analysis according to Singh and Choudhary (1977).

\section{RESULTS AND DISCUSSION 3.1. Mean performance}

Means of plant height, number of days to flowering, average fruit weight, fruit length, fruit diameter, fruit flesh thickness, early yield and total yield for seven parents and their twelve crosses of pepper are presented in Table (1).

Plant height indicated highly significant differences for parents and crosses. It ranged from $107.00 \mathrm{~cm}$ in PI (142837) to $270.33 \mathrm{~cm}$ in the cross (PI $138563 \times$ PI 209028). Data show highly significant differences among parents in number of days to flowering which ranged from 36.00 days (PI 159233) to 151.66 days (PI 159241). On the other hand, all crosses showed non significant differences for this trait. Data presented in Table (1) show significant differences of average fruit weight among all studied genotypes. The value of average fruit weight ranged from $3.66 \mathrm{~g}$ (PI $166988 \times$ PI 159241) to $21.35 \mathrm{~g}$ (PI 142837). Average fruit length showed highly significant differences among all studied genotypes. Means of fruit length ranged from 3.23 to $12.36 \mathrm{~cm}$ and PI 166988 was the tallest one $(12.36 \mathrm{~cm})$.While the crosses PI $159233 \times$ PI 209028 and PI $138563 \times$ PI $159236(6.90 \mathrm{~cm})$ were the tallest among crosses. On the other hand, the least fruit length $(3.23 \mathrm{~cm})$ was detected in the cross PI $159233 \times$ PI 159236. Data show highly significant differences among all the studied genotypes for fruit diameter. Means of fruit diameter ranged from 1.23 to $2.33 \mathrm{~cm}$. PI 166988 had the highest fruit diameter $(2.03 \mathrm{~cm})$ was in PIs while the widest crosses were PI $138563 \times$ PI 159241 and PI $159233 \times$ PI 159241 for the fruit diameter (2.33 and $2.03 \mathrm{~cm}$, respectively). Data show non significant differences among all genotypes for fruit flesh thickness. Average fruit flesh thickness ranged from 0.20 to $0.37 \mathrm{~cm}$. Early yield show highly significant differences among all the studied genotypes. Means of early yield / plant ranged from 53.33 to $370.00 \mathrm{~g}$, where the PI 159236 was the earliest $(370.00 \mathrm{~g})$ followed by the cross PI $166988 \times$ PI 159241 $(366.67 \mathrm{~g})$. On the other hand, the lowest early yield was produced by PI 209028 (53.33) g. Data show significant differences among all the studied 


\begin{tabular}{|c|c|c|c|c|c|c|c|c|c|}
\hline Sources & d.f. & $\begin{array}{c}\text { Plant } \\
\text { height } \\
(\mathrm{cm})\end{array}$ & $\begin{array}{l}\text { No. of days to } \\
\text { flowering }\end{array}$ & $\begin{array}{l}\text { Average fruit } \\
\text { weight (g) }\end{array}$ & $\begin{array}{r}\text { Fruit } \\
\text { length } \\
(\mathrm{cm})\end{array}$ & $\begin{array}{l}\text { Fruit diameter } \\
\text { (cm) }\end{array}$ & $\begin{array}{c}\text { Fruit flesh } \\
\text { thickness }(\mathrm{cm})\end{array}$ & $\begin{array}{c}\text { Early yield } \\
\text { / plant (g) }\end{array}$ & $\begin{array}{l}\text { Total yield } \\
\text { /plant }(\mathrm{kg})\end{array}$ \\
\hline Genotypes & 18 & $9681.00^{* *}$ & $4220.20^{* *}$ & 70.00** & $12.61^{* *}$ & $0.28^{* * *}$ & $0.84^{* *}$ & $20.15^{* *}$ & $34.20^{* *}$ \\
\hline Parents & 6 & $1809.80^{\mathrm{NS}}$ & 9183.70** & $120.51^{* *}$ & $22.35^{* *}$ & $0.20^{* *}$ & $0.09^{\mathrm{NS}}$ & $36.66^{* *}$ & $38.10^{* *}$ \\
\hline Parents vs Crosses & 1 & ${ }^{110043.0}{ }^{*}$ & $18037.70^{* *}$ & $475.80^{* * *}$ & $51.80^{* * *}$ & $0.14^{\mathrm{NS}}$ & $0.02^{\mathrm{NS}}$ & $21.10^{* *}$ & $1.80^{\mathrm{NS}}$ \\
\hline Crosses & 11 & $4850.41^{* *}$ & $256.71^{* * *}$ & $4.85^{* *}$ & $3.73^{* *}$ & $0.33^{* *}$ & $0.09^{\mathrm{NS}}$ & $11.78^{* *}$ & $0.93^{\mathrm{NS}}$ \\
\hline Line & 3 & $5594.20^{* *}$ & $514.84^{* *}$ & $0.77^{\mathrm{NS}}$ & $1.70^{\mathrm{NS}}$ & $0.35^{* *}$ & $0.01^{\mathrm{NS}}$ & $16.50^{* *}$ & $0.50^{\mathrm{NS}}$ \\
\hline Tester & 2 & $1014.30^{\mathrm{NS}}$ & $257.35^{\mathrm{NS}}$ & $0.50^{\mathrm{NS}}$ & $0.63^{\mathrm{NS}}$ & $0.60^{* *}$ & $0.01^{\mathrm{NS}}$ & $11.26^{* *}$ & $2.50^{\mathrm{NS}}$ \\
\hline Line $x$ Tester & 6 & $5588.20^{* * *}$ & $127.43^{\mathrm{NS}}$ & $8.70^{* *}$ & $7.30^{* *}$ & $0.24^{* * *}$ & $0.06^{\mathrm{NS}}$ & $9.62^{* * *}$ & $0.65^{\mathrm{NS}}$ \\
\hline Error & 36 & 697.55 & 56.03 & 1.48 & 0.58 & 0.04 & 0.01 & 1300.70 & 0.024 \\
\hline$\sigma^{2}$ gca & 6 & 118.04 & 19.57 & 0.42 & 0.32 & 0.01 & 0.003 & 32.672 & $\mathbf{0 . 0 3}$ \\
\hline$\sigma^{2}$ sca & 18 & 1630.21 & 23.80 & 2.40 & 2.24 & 0.06 & 0.016 & 3735.88 & 0.18 \\
\hline $\begin{array}{l}\text { Average degree of } \\
\text { dominance (ADD) }\end{array}$ & & 2.63 & 0.61 & 2.83 & 1.90 & 1.74 & 1.72 & 2.40 & 1.77 \\
\hline
\end{tabular}


genotypes for total yield. Means of total yield / plant ranged from 1.03 to $2.88 \mathrm{~kg} /$ plant. PI 166988 produced the highest total yield $(2.63 \mathrm{~kg} /$ plant) and the cross PI $138563 \times$ PI 159241 produced $2.88 \mathrm{~kg} /$ plant. On the other hand, the lowest total yield / plant was produced by PI 209028.

\subsection{Analysis of variance and type of gene action effects}

Mean squares and estimates of combining ability for all the studied traits are presented in Table (2). The differences between genotypes were highly significant for all traits indicating that the seven genotypes differed from each other in genetic components. Highly significant differences were detected among parents, parents vs crosses and crosses for the number of days to flowering, average fruit weight, fruit length and early yield / plant. Highly significant differences were detected among lines for plant height, number of days to flowering, fruit diameter and early yield, meanwhile, non significant differences were detected among tester for all studied characters except for fruit diameter and early yield. The interaction between lines and testers was highly significant for all studied trait except for number of days to flowering, fruit flesh thickness and total yield. High estimates of Average degree of dominance were detected for all studied traits except for the nnumber of days to flowering, indicating that the non- additive component played the major role for plant height, average fruit weight, fruit length, fruit diameter, fruit flesh thickness, early yield and total yield. Similar results were obtained by Miranda et al. (1988 a \&b), Khalil et al. (1989), Sahoo et al. (1989), Mulge and anand (1997) and El-Sayed (2004). On the other hand, the additive component played the major role for the number of days to flowering. These results agree with the findings of Velaskes (1981) and Ahmed et al. (1997).

\subsection{Combining ability effects}

Estimates of GCA and SCA for plant height, number of days to flowering, average fruit weight, fruit length, fruit diameter, fruit flesh thickness, early yield and total yield for seven parents and their twelve crosses of pepper are presented in Tables ( 3 and 4$)$.

For plant heigh, all evaluated pls except lp 159241 and Pi 166988 exhibited positive and negative significant GCA effects. In respect of GCA the pls138563 and PI 142837 were the best combiners for the number of days to flowing as

2. PI 166988 was the best parent for early yield and PI 142837 was the best parent for fruit length and fruit flesh thickness. they had the lowest significant values GCA (Table 3). Concerning the average fruit weight, the evaluated PIs showed significant GCA effect (Table 3). PIs 142837, PI 166988 and PI 138563 were the best combiners for fruit length (Table 3 ). In respect to the GCA effects all PIs except the PI 209028 and PI 142837showed positive significant GCA for fruit diameter (Table 3). The PI 142837 was the only line that showed positive significant differences for the GCA effects in fruit flesh thickness (Table 3 ).

The PIs 159241, PI 159236 and PI 166988 were the best combiners for early yield (Table 3 ). For total yield the PIs 209028, PI 159241 and PI 138563 were the best combiners (Table 3).

Estimates of SCA effects for the evaluated characters are presented in Table (4). Estimation of SCA effects proved that the cross PI $166988 \times$ PI 159236 was the best cross for plant height (Table 4). In respect of SCA effects the cross PI $142837 \times$ PI 159236 was the earliest cross (Table 4). Estimation of SCA effects for average fruit weight proved that the cross PI $142837 \times$ PI 159241 gave the highest significant value (Table 4). Estimation of specific combining ability effects for fruit length proved that the hybrid PI $159233 \times$ PI 209028 and PI $166988 \times$ PI 159236 gave the highest significant SCA (Table 4). In respect of SCA effects for fruit diameter revealed that the hybrid PI $166988 \times$ PI 159241 was the widest hybrid (Table 4). For fruit flesh thickness only cross PI $138563 \times$ PI 159236 showed positive significant SCA value (Table 4). Estimation of SCA effects for early yield proved that all hybrids except the hybrid PI $159233 \times$ PI 209028 and PI $166988 \times$ PI 159236 showed significant negative and positive differences in SCA (Table 4). While the estimation of SCA effects revealed that the hybrid PI $159233 \times$ PI 209028, PI $138563 \times$ PI 159241 , PI $142837 \times$ PI 159236, PI $166988 \times$ PI 209028 and PI $166988 \times$ PI 159236 showed significant positive differences in total yield (Table 4).

\section{Conclusion:}

1. Significant differences were found among the tested genotypes for all the studied traits except for fruit flesh thickness and non additive gene played the major role in the inheritance of plant height, average fruit weight, fruit length, fruit diameter, fruit flesh thickness, early yield and total yield, meanwhile, additive gene played the major role in the inheritance of the number of days to flowering.

3. The most superior cross was PI $166988 \times$ PI 159236, since it possessed highly significant 
Table (2): Analysis of variance and estimates of combining ability for eight characters of $\mathrm{L} x \mathrm{~T}$ analysis of pepper during the season $2006 / 2007$

\begin{tabular}{|c|c|c|c|c|c|c|c|c|c|}
\hline Sources & d.f. & $\begin{array}{c}\text { Plant } \\
\text { height } \\
(\mathrm{cm})\end{array}$ & $\begin{array}{l}\text { No. of days to } \\
\text { flowering }\end{array}$ & $\begin{array}{c}\text { Average fruit } \\
\text { weight (g) }\end{array}$ & $\begin{array}{r}\text { Fruit } \\
\text { length } \\
(\mathrm{cm})\end{array}$ & $\begin{array}{c}\text { Fruit diameter } \\
(\mathrm{cm})\end{array}$ & $\begin{array}{c}\text { Fruit flesh } \\
\text { thickness }(\mathrm{cm})\end{array}$ & $\begin{array}{c}\text { Early yield } \\
\text { / plant (g) }\end{array}$ & $\begin{array}{l}\text { Total yield } \\
\text { /plant }(\mathrm{kg})\end{array}$ \\
\hline Genotypes & 18 & $9681.00^{* * *}$ & $4220.20^{* * *}$ & $70.00^{* *}$ & $12.61^{* *}$ & $0.28^{* * *}$ & $0.84^{* *}$ & $20.15^{* *}$ & $34.20^{* *}$ \\
\hline Parents & 6 & $1809.80^{\mathrm{NS}}$ & $9183.70^{* *}$ & $120.51^{* * *}$ & $22.35^{* *}$ & $0.20^{* *}$ & $0.09^{\mathrm{NS}}$ & $36.66^{* *}$ & $38.10^{* *}$ \\
\hline Parents vs Crosses & 1 & $\begin{array}{c}110043.0^{*} \\
*\end{array}$ & $18037.70^{* * *}$ & $475.80^{* *}$ & $51.80^{* *}$ & $0.14^{\mathrm{NS}}$ & $0.02^{\mathrm{NS}}$ & $21.10^{* * *}$ & $1.80^{\mathrm{NS}}$ \\
\hline Crosses & 11 & $4850.41^{* * *}$ & $256.71^{* * *}$ & $4.85^{* *}$ & $3.73^{* *}$ & $0.33^{* *}$ & $0.09^{N S}$ & $11.78^{* *}$ & $0.93^{\mathrm{NS}}$ \\
\hline Line & 3 & $5594.20 * *$ & $514.84^{* *}$ & $0.77^{\mathrm{NS}}$ & $1.70^{\mathrm{NS}}$ & $0.35^{* *}$ & $0.011^{\mathrm{NS}}$ & $16.50^{* *}$ & $0.50^{\mathrm{NS}}$ \\
\hline Tester & 2 & $1014.30^{\mathrm{NS}}$ & $257.35^{\mathrm{NS}}$ & $0.50^{\mathrm{NS}}$ & $0.63^{\mathrm{NS}}$ & $0.60^{* *}$ & $0.01^{\mathrm{NS}}$ & $11.26^{* *}$ & $2.50^{\mathrm{NS}}$ \\
\hline Line $x$ Tester & 6 & $5588.20^{* * *}$ & $127.43^{\mathrm{NS}}$ & $8.70^{* * *}$ & $7.30^{* *}$ & $0.24^{* *}$ & $0.06^{\mathrm{NS}}$ & $9.62^{* *}$ & $0.65^{\mathrm{NS}}$ \\
\hline Error & 36 & 697.55 & 56.03 & 1.48 & 0.58 & 0.04 & 0.01 & 1300.70 & 0.024 \\
\hline$\sigma^{2}$ gca & 6 & 118.04 & 19.57 & 0.42 & 0.32 & 0.01 & 0.003 & 32.672 & $\mathbf{0 . 0 3}$ \\
\hline$\sigma^{2}$ sca & 18 & 1630.21 & 23.80 & 2.40 & 2.24 & 0.06 & 0.016 & 3735.88 & 0.18 \\
\hline $\begin{array}{l}\text { Average degree of } \\
\text { dominance (ADD) }\end{array}$ & & 2.63 & 0.61 & 2.83 & 1.90 & 1.74 & 1.72 & 2.40 & 1.77 \\
\hline
\end{tabular}


Table (3) : General combining ability (GCA) effects of seven pepper parents for plant height, number of days to flowering, average fruit weight, fruit length, fruit diameter, fruit flesh thickness, early yield and total yield during 2006/2007 season.

\begin{tabular}{|c|c|c|c|c|c|c|c|c|}
\hline Parents ${ }^{\mathrm{Z}}$ & $\begin{array}{l}\text { Plant } \\
\text { height }\end{array}$ & $\begin{array}{l}\text { Number } \\
\text { of days to } \\
\text { flowering }\end{array}$ & $\begin{array}{c}\text { Average } \\
\text { fruit } \\
\text { weight }\end{array}$ & $\begin{array}{l}\text { Fruit } \\
\text { length }\end{array}$ & $\begin{array}{c}\text { Fruit } \\
\text { diameter }\end{array}$ & $\begin{array}{l}\text { Fruit flesh } \\
\text { thickness }\end{array}$ & $\begin{array}{l}\text { Early } \\
\text { yield }\end{array}$ & $\begin{array}{l}\text { Total } \\
\text { yield }\end{array}$ \\
\hline \multicolumn{9}{|c|}{ Testers } \\
\hline 1 & $12.38 * *$ & $4.73 * *$ & 0.23 & 0.11 & -0.02 & 0.02 & $-40.30^{* * *}$ & $0.19^{* * *}$ \\
\hline 2 & -2.77 & -.22 & -0.09 & $-0.26^{* *}$ & $\mathbf{0 . 2 3}^{* *}$ & 0.01 & $22.22^{* * *}$ & $0.48^{* * *}$ \\
\hline 3 & $-9.6 * *$ & -4.51 & -0.14 & 0.15 & $0.21^{* *}$ & 0.03 & $18.05^{* *}$ & $-.30^{* *}$ \\
\hline \multicolumn{9}{|c|}{ lines } \\
\hline 4 & $15.50 * *$ & 3.33** & 0.30 & $-0.44^{* *}$ & $0.17^{* * *}$ & 0.02 & --8.61 & $-0.23^{* * *}$ \\
\hline 5 & 23.00 & $-6.30 * *$ & -0.02 & $0.33^{* *}$ & $0.16^{* *}$ & -0.03 & $-30.80^{* *}$ & $0.26^{* * *}$ \\
\hline 6 & $-32.50 * *$ & $-6.14 * *$ & -0.23 & $0.40^{* *}$ & $-0.15^{* *}$ & $0.04^{* *}$ & $-31.94^{* *}$ & 0.02 \\
\hline 7 & -6.00 & $9-11 * *$ & -0.26 & $0.30^{* *}$ & $0.18^{* *}$ & -0.02 & $71.40^{* *}$ & $-0.26^{* *}$ \\
\hline SE tester & 7.62 & 2.16 & 0.86 & 0.21 & 0.06 & 0.04 & 10.41 & 0.04 \\
\hline SE lines & 8.80 & 2.50 & 0.40 & 0.25 & 0.07 & 0.03 & 12.02 & 0.05 \\
\hline $\begin{array}{l}\mathrm{SE}\left(\mathrm{g}_{\mathrm{i}^{-}}\right. \\
\left.\mathrm{g}_{\mathrm{j}}\right) \text { tester }\end{array}$ & 10.78 & 3.05 & 0.50 & 0.31 & 0.08 & 0.04 & 14.72 & 0.06 \\
\hline $\mathrm{SE}\left(\mathrm{g}_{\mathrm{i}}-\mathrm{g}_{\mathrm{j}}\right)$ line & 12.45 & 3.52 & 0.57 & 0.35 & 0.10 & 0.05 & 17.00 & 0.07 \\
\hline
\end{tabular}

Z 1:PI20902; 2:PI159241; 3:PI159236; 4:PI1592331; 5:PI138563; 6:PI142837and 7:PI166988.

Table (4): Specific combining ability (SCA) effects of twelve crosses of pepper for plant height, number of days to flowering, average fruit weight, fruit length, fruit diameter, fruit flesh thickness, early yield and total yield during 2006/2007 season.

\begin{tabular}{|c|c|c|c|c|c|c|c|c|}
\hline Crosses $^{Z}$ & $\begin{array}{l}\text { Plant } \\
\text { height }\end{array}$ & $\begin{array}{l}\text { Number } \\
\text { of days to } \\
\text { flowering }\end{array}$ & $\begin{array}{c}\text { Average } \\
\text { fruit } \\
\text { weight }\end{array}$ & $\begin{array}{l}\text { Fruit } \\
\text { length }\end{array}$ & $\begin{array}{c}\text { Fruit } \\
\text { diameter }\end{array}$ & $\begin{array}{c}\text { Fruit flesh } \\
\text { thickness }\end{array}$ & $\begin{array}{l}\text { Early } \\
\text { yield }\end{array}$ & $\begin{array}{l}\text { Total } \\
\text { yield }\end{array}$ \\
\hline $4 \times 1$ & 14.83 & 1.50 & $-1.81^{* * *}$ & $1.55^{* *}$ & -0.05 & $-0.11^{* * *}$ & 13.61 & $0.18^{* *}$ \\
\hline $4 \times 2$ & $-27.32^{\text {** }}$ & $-7.21^{* * *}$ & $0.81^{* *}$ & $0.60^{* *}$ & -0.01 & 0.03 & $-52.22^{* * *}$ & $-0.16^{* *}$ \\
\hline $4 \times 3$ & 12.5 & $5.72^{* *}$ & $1.00^{* *}$ & $-2.15^{* *}$ & 0.06 & -0.02 & 38.61 $^{* *}$ & -0.03 \\
\hline $5 \times 1$ & 9.61 & -1.39 & $0.76^{* *}$ & 0.04 & -0.11 & -0.02 & -17.50 & $-0.32^{* * *}$ \\
\hline $5 \times 2$ & 1.11 & 1.47 & $0.76^{* *}$ & $-0.78^{* * *}$ & $0.30^{* *}$ & -0.03 & $-26.60^{* * *}$ & $0.67^{* *}$ \\
\hline $5 \times 3$ & -10.72 & 1.47 & -0.63 & $0.73^{* *}$ & $-0.20^{* *}$ & $0.14^{* *}$ & $44.16^{* * *}$ & $-0.35^{* * *}$ \\
\hline $6 \times 1$ & $27.50^{* *}$ & 2.42 & -0.12 & $-0.63^{* *}$ & -0.12 & -0.05 & $56.83^{* *}$ & $-0.12^{* * *}$ \\
\hline $6 \times 2$ & $26.22^{* *}$ & -1.41 & $1.75^{* *}$ & 0.41 & $0.15^{* * *}$ & 0.05 & $34.44^{* *}$ & -0.03 \\
\hline $6 \times 3$ & $-54.16^{* * *}$ & $-16.37^{* * *}$ & $-1.62^{* *}$ & 0.22 & -0.03 & 0.03 & $-91.36^{* * *}$ & $0.15^{* *}$ \\
\hline $7 \times 1$ & $-51.94^{\text {*** }}$ & 2.62 & $1.18^{* * *}$ & -0.14 & $0.25^{* * *}$ & 0.04 & $-53.05^{* * *}$ & $0.25^{* *}$ \\
\hline $7 \times 2$ & 0.44 & $9.66^{* *}$ & $-1.92^{* *}$ & $-0.71^{* * *}$ & $0.47^{* *}$ & -0.04 & $44.44^{* *}$ & $-0.50^{* *}$ \\
\hline $7 \times 3$ & $46.38^{* *}$ & $-7.04^{* * *}$ & $0.73^{* *}$ & $1.20^{* *}$ & $0.15^{* *}$ & 0.03 & 8.61 & $0.23^{* *}$ \\
\hline SE SCA & 15.24 & 4.32 & $\begin{array}{l}0.70 \\
\end{array}$ & 0.43 & 0.12 & 0.07 & 20.82 & 0.09 \\
\hline $\operatorname{SE}\left(\mathbf{s}_{\mathrm{ij}} \mathbf{s}_{\mathrm{kl}}\right)$ & 21.56 & 6.11 & 1.00 & 0.62 & 0.24 & 0.1 & 29.44 & 0.12 \\
\hline
\end{tabular}

Z 1:PI20902; 2:PI159241; 3:PI159236; 4:PI1592331; 5:PI138563; 6:PI142837and 7:PI166988.

and positive SCA effects in plant height, average fruit weight, fruit length, fruit diameter and total yield and possessed highly significant and negative SCA effects in the number of days to flowering.

\section{REFERENCES}

Ahmed N., Nayeema J. and Tanki M. I. (1997). Combining ability analysis for fruit yield and its component characters in sweet pepper (Capsicum annuum L.).Capsicum \& Eggplant Newsletter Vol. 16: 72-75. (c.a. Plant Breed. Abstr. 68: 5951, 1998).

Ahmed N., Shah F.A., Zargar G. H. and Wani S. A. (1998). Line $x$ tester analysis for the study of combining ability in hot pepper (Capsicum annuum L.).Capsicum \& Eggplant, Newsletter Vol. 17: 38-41. 
El-Sayed A. A.(2004). Hybrid Seed Production of Pepper Under Protection. M. Sc. Thesis, Fac. Agric., Cairo Univ., Egypt. 147pp.

Khalil R. M., Malash N. M. and Konsuwa A. M. (1989). Studies on gene action for some quantitative characters in pepper (Capsicum annuum L.) Minufiya .J. Agri. Res. Vol. 14 (2): 969-981.

Miranda J. E. C.DE, Costa CP. DA. and Cruz CD. (1988a). Diallel analysis in sweet pepper. I. Combining ability. Revista Brasileira de Genetica. Vol. 11 :2:431-440. (c.a. Plant Breed. Abstr. 58: 10838,1988).

Miranda J. E. C. DE., Costa CP. DA. and Maluf W. F. (1988b). Diallel analysis in sweet pepper. II. Genetic components of variance. (In Portuguese with English summary). Revista Brasileira de Genetica. Vol. 11(2):441-456. (c. a. Plant Breed. Abstr.58:10839,1988).

Mulge R. and Anand N. (1997). Identification of sweet pepper (Capsicum annuum L.) lines to develop $F_{1}$ hybrids resistant to powdery mildew. Indian Journal of Genetics and Plant Breeding Vol. 57(2): 193-199.

Patel J. A., Shukla M.R., Doshi K.M. and Patel S.A. (1998). Combining ability analysis for green fruit yield \& yield components in chilli (Capsicum annuum L.). Capsicum \& Eggplant Newsletter Vol. 17:34-36.

Sahoo S. C., Mishra S. N., Mishra R. S. and Lotha R. E. (1989). Combining ability and components of genetic variance for four preharvest characters in Chilli (Capsicum annuum L.). South Indian Horticulture Vol 37(5): 270-273. (c. a. Plant Breed. Abstr.62: 679,1992).

Singh R. K. and Choudhary B. D. (1977). Biometrical Methods in Quantitative Genetic Analysis. USHA Rei Kumar for Kalyani Publisher, Ludhiana, India, p130178.

Velaskes F. R. (1981). Bulgarian heterotic hybrids of pepper (Capsicum annuum L.) grown in Cuba. II. Growth phases, plant height and leaf area. (in $\mathrm{Bg}$ with English summary). Genetika I Selekstiya Vol. 14(3):246-251. (c. a. Plant Breed. Abstr.52: 863,1982).

Waller R.A. and Duncan, D.B. (1969) A bays rule for the symmetric multiple comparison problems. Amer. Stat. Assoc. J. 64; 14851503.

\section{(Capsicum annuum L.) دراسة القدرة على الايتلاف فى الفلقل الحريف (Capsicum chinense Jacq.) line x tester باستخدام تحليل}

أحمد حسن خريبة ـ أحمد على غريب - سيد محمد محمود*- ياسر محمد أحمد - عبير عبد القادر السيد

قسم الخضر - كلية الزر اعة- جامعة القاهرة- الجيزة

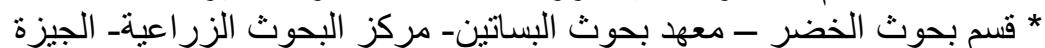

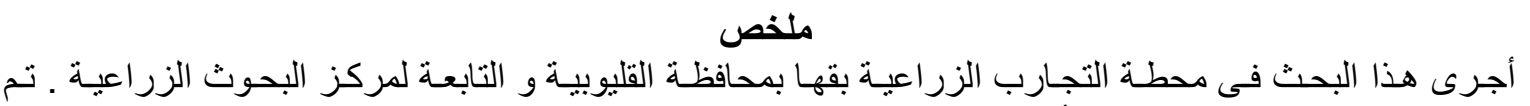

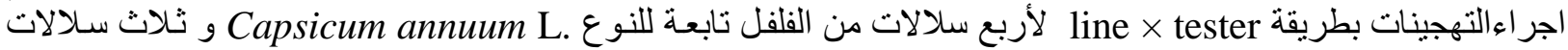
تابعة للنوع .Capsicum chinense Jacq وتم تقدير القدرة على الائتلاف لثمانى صفات ـ وجدت إختلافات معنويـة بين

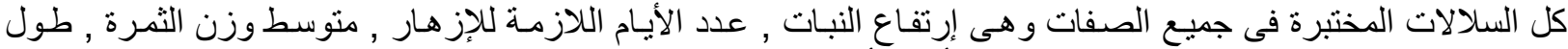

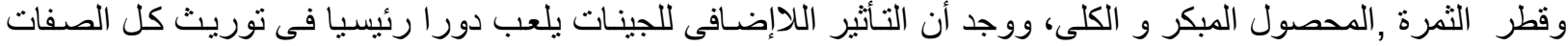
فيما عدا صفة عدد الأيام اللازمة للإز هار ـ. أوضحت در اسة القدرة العامة على الائتلاف أن السلالة

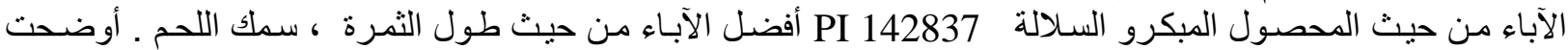

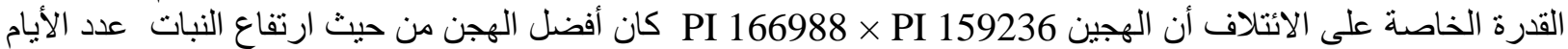

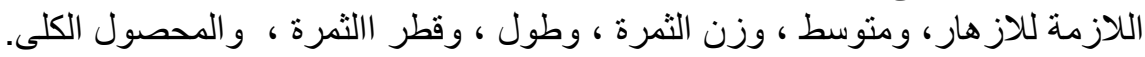

